\title{
Is fosfomycin as effective as claimed on MDR Gram-negative bacteria causing UTI? [Letter]
}

This article was published in the following Dove Press journal: Infection and Drug Resistance

\section{Geeta Singh' \\ BR Singh ${ }^{2}$}

'Independent Science Analyst, Bareilly, UP 24300I, India; ${ }^{2} \mathrm{Head}$ Division of Epidemiology, Indian Veterinary Research Institute, Bareilly, India
Correspondence: Geeta Singh Independent Science Analyst, 23A Vaibhav Suncity Vistaar, Bareilly, UP 24300I, India Tel +9l 99170207724

Email geetasti45@gmail.com

\section{Dear editor}

In a recently published paper ${ }^{1}$ fosfomycin is claimed to be an effective antibiotic on Gram-negative bacteria (GNBs) causing urinary tract infections (UTIs) in Pondicherry in Southern India. Monotherapy of fosfomycin is not recommended due to chances for development of resistance during therapy is a serious concern ${ }^{2}$ therefore the authors suggested using fosfomycin with amoxyclav and nitrofurantoin. ${ }^{1}$ Researchers reported fosfomycin as the most effective antibiotic inhibiting $100 \%$ E. coli, $70 \%$ Klebsiella sp., and 50\% Pseudomonas sp. and $40 \%$ Enterobacter sp. isolates from UTIs. Fosfomycin was also effective against extended-spectrum $\beta$-lactamases (ESBL), carbapenemase and $\mathrm{AmpC}^{1}$ producers. A recent report from Bareilly ${ }^{3}$, Northern India indicated E. coli as the most common bacteria associated with UTI infections both in humans and animals similar to the report from Pondicherry. ${ }^{1}$ However, the report from Northern India reported only that only $12.9 \%$ and $33.3 \%$ isolates of GNBs associated with UTIs in humans and animals were susceptible to fosfomycin. The study ${ }^{3}$ reported that only $8.3 \%$ and $25 \%$ of E. coli isolates from UTI cases were susceptible to fosfomycin. The two studies ${ }^{1,3}$ concurred (Table 1) each other concerning the efficacy of meropenem and nitrofurantoin but contradicted each other for the susceptibility of E. coli isolates (Table 1) and other GNBs from UTIs to other antibiotics.

Table I Susceptibility patterns of Escherichia coli associated with urinary tract infections

\begin{tabular}{|l|l|l|l|}
\hline $\begin{array}{l}\text { Antimicrobials } \\
\text { tested }\end{array}$ & $\begin{array}{l}\text { Percent sensitive isolates under } \\
\text { study in Pondicherry' }\end{array}$ & \multicolumn{2}{|l|}{$\begin{array}{l}\text { Percent sensitive isolates under } \\
\text { study in Bareilly }\end{array}$} \\
\cline { 2 - 4 } & E. coli, human cases (n=2 17) & $\begin{array}{l}\text { E. coli, human } \\
\text { cases (n=50) }\end{array}$ & $\begin{array}{l}\text { E. coli, animal } \\
\text { cases (n=37) }\end{array}$ \\
\hline Fosfomycin & 100 & 8.3 & 25.0 \\
Nitrofurantoin & 86.6 & 89.4 & 78.4 \\
Ciprofloxacin & 0.0 & 14.6 & 29.7 \\
Gentamicin & 4.6 & 60.0 & 45.9 \\
Meropenem & 84.3 & 80.6 & 87.1 \\
Ceftriaxone & 0.5 & 31.7 & 50.0 \\
Ceftazidime & 6.9 & 40.7 & 46.7 \\
\hline
\end{tabular}


Looking at both of the studies, ${ }^{1,3}$ we understand a wide variation in susceptibility (Table 1) of the bacteria from different regions and different patients causing similar infections. Thus, a generalization of observation should be avoided for suggesting or using antimicrobial chemotherapy, and more elaborate and continues surveys and monitoring the antimicrobial drug-resistance of important pathogens should be established and regularly published for proper guidance of the clinicians.

\section{Disclosure}

The authors report no conflicts of interest in this communication.

\section{References}

1. Gopichand P, Agarwal G, Natarajan M, et al. In vitro effect of fosfomycin on multi-drug resistant gram-negative bacteria causing urinary tract infections. Infect Drug Resist. 2019;12:2005-2013. doi:10.2147/ IDR.S207569

2. Hardisson C, Villar CJ, Llaneza J, Mendoza MC. Prevalence and dispersion of plasmids conferring fosfomycin resistance in enterobacteria. Pathol Biol (Paris). 1984;32(7):755-758.

3. Singh BR 2019. Urinary tract infections: the most common causes and effective antimicrobials. Technical Report, UTI-1, Izatnagar: Indian Veterinary Research Institute. Available from: https://www.research gate.net/publication/334544575_Urinary_tract_infections_The_most_ common_causes_and_effective_antimicrobials. doi: 10.13140/RG.2.2. $31538.56005 / 1$ Dove Medical Press encourages responsible, free and frank academic debate. The content of the Infection and Drug Resistance 'letters to the editor' section does not necessarily
represent the views of Dove Medical Press, its officers, agents, employees, related entities or the Infection and Drug Resistance editors. While all reasonable steps have been taken to
confirm the content of each letter, Dove Medical Press accepts no liability in respect of the content of any letter, nor is it responsible for the content and accuracy of any letter to the editor.

\section{Publish your work in this journal}

Infection and Drug Resistance is an international, peer-reviewed openaccess journal that focuses on the optimal treatment of infection (bacterial, fungal and viral) and the development and institution of preventive strategies to minimize the development and spread of resistance. The journal is specifically concerned with the epidemiology of antibiotic resistance and the mechanisms of resistance development and diffusion in both hospitals and the community. The manuscript management system is completely online and includes a very quick and fair peerreview system, which is all easy to use. Visit http://www.dovepress.com/ testimonials.php to read real quotes from published authors. 